\title{
THE MODERATING ROLE OF BRANDS FOR LOW INCOME LUXURY CONSUMERS
}

Flávio Santino Bizarrias Universidade Nove de Julho, Brazil E-mail: flavioxsp@hotmail.com

Suzane Strehlau Universidade CEUMA, Brazil E-mail: strehlau@gmail.com

Marcelo Moll Brandão Universidade Federal do Espírito Santo, Brazil

E-mail: mollmkt@gmail.com

Submission: 23/02/2017 Accept: 01/03/2017

\section{ABSTRACT}

The value of luxury is a multidimensional construct that assesses how consumers consider the various dimensions of luxury in their consumption relations. The consumption of luxury is not a trivial activity for most people, but brings a certain fascination and is part of the imaginary of the lower classes in emerging markets. The social identity of these consumers is changing because they aspire a new social position. But luxury consumption hurts the standards of this consumer profile. At the same time the self esteem is observed as an important element of people self-confirmation. For consumers, specifically, self-esteem is an important antecedent of consumption decisions. A sample of low income students was analyzed in this study to describe their relationship with luxury, and its influence on self-esteem when moderated by brand expressiveness. Through structural equation modeling this study found that the expression of the brand moderates the relationship of the value of luxury with selfesteem, allowing consumers of lower classes to observe a significant role of luxury in their lives. 
INDEPENDENT JOURNAL OF MANAGEMENT \& PRODUCTION (IJM\&P)

http://www.ijmp.jor.br

V. 8, n. 3, July - September 2017

ISSN: 2236-269X

DOI: 10.14807/ijmp.v8i3.639

Keywords: Emerging markets; Luxury; Brand expressiveness; Consumer behavior

\section{INTRODUCTION}

The luxury products market is growing worldwide. The luxury market grew $10 \%$ in terms of revenues between 2013 and 2014 (EUROMONITOR, 2015). It is a market recognized as having high rates of profitability (KAPFERER, 2014). The forecast is that demand for handbags and watches will continue to grow as it clearly signals wealth and status among consumers in both developed and emerging markets. Brands like Michael Kors, ToryBurch and Kate Spade have benefited from what's called affordable luxury (EUROMONITOR, 2015).

New clients of luxury goods can choose brands because of the contagiation experienced in seeing luxury goods being used by their acquaintances, not for adherence to brand values or knowledge about tis category (KAPFERER, 2015). Xianchi and Fishbach (2014) proposes that the desire for goods depends on the duration of non-consumption (abstention), and the presence of surrogates that are salient, that is, if substitutes are not present the period of non-consumption will increase desire.

On the other hand, many consumers seek counterfeit brands and products to satisfy their desire for distinction in the social groups they occupy (STREHLAU, 2008). This is due to its lower economic condition, or for not wanting to spend with this category of products. Even if the mechanisms that motivate the traditional luxury consumer seem to be different from those that motivate lower-income consumers to acquire more sophisticated products, the motivation to seek out distinctive symbols seems to be common to people in general.

However, many organizations neglect lower-income consumers as the target of their business strategies (NGUYEN; SIMKIN, 2013). On the one hand, this choice is proven to preserve the brand equity built. But this choice does not eliminate the possibility for lower-income consumers themselves to pursue sophistication in their choices of consumption as self-assertion of themselves and their social group. The observed social and economic changes of the past decades in emerging markets have created consumer groups that are transforming the way they consume in this quest to build a clear identity (SARAIVA, et al., 2015). 
INDEPENDENT JOURNAL OF MANAGEMENT \& PRODUCTION (IJM\&P)

http://www.ijmp.jor.br

v. 8, n. 3, July - September 2017

ISSN: 2236-269X

DOI: 10.14807/ijmp.v8i3.639

In emerging markets these groups seem to aspire for a new identity. Luxury consumption simply seems very distant from the reality of this huge contingent of consumers and would have little effect for these consumers in the social group they attend. However, brands can be the bridge between the low-income consumer and the consumption of more sophisticated products, insofar as they could broaden their identity within the reference group they belong to, without suffering any social punishment for diverting too much from the established norms when consuming luxury goods. It is worth noting that luxury has a number of perspectives beyond those concerning price as suggested by common sense (HENINGS, et al., 2012).

This consumer also has an identity in transformation. We consider selfesteem to be an important aspect for this transformation insofar as it precedes a series of consumer phenomena. Self-esteem is also linked to social identity as one of its dimensions (ELLEMERS; KORTEKAAS; OUWERKERK, 1999) in establishing a sense of belonging, and in the relationship with the group to which one belongs to.

In this study, our objective was to analyze self-esteem as a variable that will depend on the pressures of the social group and the value attributed to luxury, aiming to answer the following question: what is the influence of social identity and luxury value on the self-esteem of low-income consumers whn moderated by brand expressiveness? This study is justified by the great relevance of this group of consumers in the economy and by observing that this profile of consumers presents an identity in transformation (SARAIVA, et al., 2015), that can impact consumer studies and companies strategies.

\section{SOCIAL IDENTITY}

People act in many situations by influence of the social groups to which they belong or aspire to belong to, and for this they seek to make decisions that shape their identity. These decisions follow subjective norms, but also social pressures from those that matter to us (EAGLY; CHAIKEN, 1993).

Otherwise, social influence reflects our need for approval by the social group (compliance) in choosing a course of action. It is also observed that decisions can be made based on the congruence between personal norms and values and those of the social group that we belong to (internalization), reflecting patterns of conduct transmitted. Another mode of social influence, identification, establishes that we 
INDEPENDENT JOURNAL OF MANAGEMENT \& PRODUCTION (IJM\&P)

http://www.ijmp.jor.br

V. 8, n. 3, July - September 2017

ISSN: 2236-269X

DOI: 10.14807/ijmp.v8i3.639

make decisions that are based on the search for a relationship of positive selfdefinition with other people (BAGOZZI; KYU-HYUN, 2002).

These social influences lead people to adopt patterns that the group adopts. As in today's society it is observed that consumption is also a frequent social activity, we hope that in a situation of purchase in which the consumer does not belong to his social group, he or she will adopt the norms of his group, and will have an implicit attitude favorable to his group.

But by means of preassure of social desirability, he or she will not declare this distance from the group to which they does not belong. In other words, a low-income consumer needs to act according to the norms of its current social group, even though he or she wants to be perceived as a succesfull person through his belongins.But it may provide disapproval and, accordingly, disconfort.

Ellemers, Kortekaas and Ouwerkerk (1999) propose a model adopted in this study in which social identity is formed by commitment to the group, selfcategorization and self-esteem with the group to which one belongs. The definition of identity adopted in this study establishes that it has several parts that compose it, and one of them is social identity, or the knowledge of belonging to a social group together with the affection felt by this group.

This social identity is based on a cognitive component (awareness of belonging to the group, or self-categorization), an evaluative component (a positive or negative connotation of this belonging, or self-esteem in relation to the group) and an emotional component (sense of emotional involvement with the Group, or affective impairment). It is expected that people will act to protect its identity, and reinforce it, even though we recognize that identity is an element subject to change accross time.

\section{LUXURY}

Over the years luxury objects have been used to distinguish people in society, and today people consume certain objects or brands to distinguish themselves in society (HAN; NUNES; DRĖZE, 2010). Therefore, luxury helps to shape people identity, and people social identity. Luxury is based on a motivational process based on need and desire. Thus, luxury is associated with desire, in contrast to needs. (KEMP, 1998). 
INDEPENDENT JOURNAL OF MANAGEMENT \& PRODUCTION (IJM\&P)

http://www.ijmp.jor.br

V. 8, n. 3, July - September 2017

ISSN: 2236-269X

DOI: 10.14807/ijmp.v8i3.639

Vigneron and Johnson (1999) define luxury as being marks of a higher level that possess physical values but, above all, psychological ones that by their simple use already bring self-esteem to its possessor. This category of consumption responds to the need that people have of distinction and to feel belonging to groups they aspire to, far from the common mass of people (LEIBENSTEIN, 1950). However, not only are psychological benefits associated with luxury, but their value is also seen in other dimensions.

\subsection{Value of luxury}

Several authors have sought to measure the value of luxury. Wiedmann, Hennigs and Siebels (2007) propose a scale to measure the value of luxury in four dimensions. Luxury brings psychological values but also represents values in other dimensions as financial value, quality value, individual and social (HENINGS, et al., 2012). Financial Value precisely establishes issues related to the monetary aspects of luxury, such as price, resale and investment.

Functional value refers to durability, and its utility function and reliability. Individual Value deals with the consumer's internal and personal motivations and psychological traits in possessing luxury goods such as materialism, hedonism, and self-identity. The dimension Social value of luxury deals with the social recognition that is attributed to those who possess luxury goods, deals with the prestige acquired and the conspicuousness.

Henings et al. (2012) measured the value of luxury in different cultures. The study examined whether the perception of luxury varies between countries. Data were collected in 10 countries, Brazil, France, Germany, Hungary, India, Italy, Japan, Slovakia, Spain and the USA and significant differences were identified among countries. Brazilians stood out as admirers of luxury.

Linking possessions to the extent of one's identity is important in understanding consumer choices. The value of luxury is symbolic in this sense, since it is not a matter of having the luxury to have a better use of the product, but to demonstrate to the other members of the group that one has a distinction. The income that people possesses and, therefore, their social class is an important factor in identifying who consumes and values luxury (DUBOIS; DUQUESNE, 1993). 
INDEPENDENT JOURNAL OF MANAGEMENT \& PRODUCTION (IJM\&P)

http://www.ijmp.jor.br

v. 8, n. 3, July - September 2017

ISSN: 2236-269X

DOI: 10.14807/ijmp.v8i3.639

The means and assets that people possess influence luxury consumption (HAN; NUNES; DRÈZE, 2010). Cultural issues also play a decisive role in the notion of what we consider to be luxury. That which is luxury brings to the owner distinction, prestige, and status, and some societies have more of this motivation to express themselves through what they possess.

However, there seems to be a greater need among people with lower income, particularly in developing countries, where after years of restriction to more common goods, increasing consumption is moving towards more sophisticated goods, more motivated for prestige than by its functional aspects. This has been observed in recent years in Brazil (ESTADÃO, 2012; EXAME, 2013) and other similar countries,(YE; LIU; SHI, 2015) in emerging markets.

For this group of consumers we expect that the function of the brand, particularly those that express luxury, should play a relevant role in the relationship of low income consumers with luxury. We hypothesize that for the less favored classes, luxury will have a more aspirational character, and that brands will enable low-income consumers to approach luxury goods without discomfort when the brand can represent its identity, not the product itself.

\section{BRAND EXPRESSIVINESS}

Brands and objects play an important role in corporate strategies, as well as in people's lives. Brands help us to give meaning to who we are and the world around us. In their social role as consumer, people incorporate objects, such as brands to their identities through buying and living situations (BELK, 1988; SHIMP; MADDEN, 1988; DAY, 1989).

Several examples of the incorporation and extension of self are found in mankind. From antiquity, when the rituals in which the dead were buried with their objects, or when, in some cultures, some groups feed on their enemies, so that their spirit, and their forces, are part of that of the conqueror.

The creation of objects reflects the identity of its creator, and the loss of an object resembles the loss of a loved one. The use of an automobile turns our notion of who we are. The purchase and use of an object as well. Even in actions of vandalism, as a form of aggression to the social identity of society as a whole we observe the symbolic role of objects in our lives. Or, the link between the farmer and 
INDEPENDENT JOURNAL OF MANAGEMENT \& PRODUCTION (IJM\&P)

http://www.ijmp.jor.br

v. 8, n. 3, July - September 2017

ISSN: 2236-269X

DOI: 10.14807/ijmp.v8i3.639

the land he cultivates is another example of the relationship between people and objects (BELK, 1988).

Brands can function the same way, as being part of people identity, an shaping it. When a brand expresses the feelings and thoughts a person have about itself we can observe brand expressiveness, or when a brand "[...] enhances one's social self and/or reflects one's inner self", (CARROL; AHUVIA, 2006, p. 82).

It follows that brand expressiveness can affect the relationship people have with other dimensions that shape one's identity, like social groups they belong to or desire to be part of, and with other objects that have the same function of modeling their identity, like luxury goods. We hypothesize that brand expressiveness can moderate this relations that shapes consumer identity, and as a result, their selfesteem.

The most prominent brands can express status (HAN; NUNES; DRÈZE, 2010) and this can be important to low income consumers, for their self-esteem, and their sense of group and individual identity. These authors propose four classifications of consumers of luxury, or sophisticated objects. The Patricians, or consumers who have great purchasing power, and pay premium prices for products not remarkable because they have a greater desire to approach other patricians than to dissociate from other social groups.

The second group is called Parvenus, or consumers who have high incomes but no knowledge to distinguish symbols of exclusivity like the patricians, they yearn for status. The third group is called Poseurs, a French word without similar in the Portuguese language and that designates the people who pretend to be what they are not. These consumers do not have high incomes, and they have a great need for status. Finally, the group of consumers called Proletarians, that is, consumers without the need of status and without high income.

There is no need to approach higher groups or to disassociate with other groups. In this study, the consumer group is closer to the Poseurs. This group of consumers looks for in the most sophisticated products and brands a form of status and privilege, which in many ways resembles a way of occupying a space in the society that they did not have before. This self-assertion as a relevant social group 
INDEPENDENT JOURNAL OF MANAGEMENT \& PRODUCTION (IJM\&P)

http://www.ijmp.jor.br

v. 8, n. 3, July - September 2017

ISSN: 2236-269X

DOI: 10.14807/ijmp.v8i3.639

can be established through self-esteem in which its achievements and identity are shown in a different way from other more favored social groups.

\section{SELF-ESTEEM}

Self-esteem is about people's assessment of themselves. This evaluation can then be used for a series of subsequent decisions (ROSENBERG, 1986). Gecas (1982) proposes that the self-esteem can be composed of two dimensions. One characterized by the capacity of realization of the people, and another by the value that is attributed to itself. Cast and Burke (2002) proposed a theory of self-esteem that addresses both self-esteem as a result of behaviors (dependent), and as a protection mechanism and motivation factor for future behaviors (mediation).

All these approaches can be used in the context of consumer behavior. We can consume brands and products that increase the value we observe in ourselves before others, as in the consumption of luxury products or brands that give us prestige and status, or protection against social punishment coming from groups that do not aspire to participate.

The level of self-esteem (high or low) will have an impact on future decisions, but from another perspective, some factors may influence the level of consumer selfesteem. Insofar as the value attributed to luxury leads the consumer to reflect on the role that the most sophisticated products and brands exert in their life, the consumer will suffer a greater or lesser influence of this category of products and brands on their attitude toward themselves, their self-esteem.

In this study we adopted the perspective of self-esteem as a result of situations evaluated by the consumer, in which he or she considers its relationship with luxury in the search for social approval.

\section{THEORETICAL MODEL AND DEVELOPMENT OF HYPOTHESES}

For the accomplishment of this study a conceptual model was developed based on the literature review presented. Social Identity constitutes the part of the self of the person who represents the vision that the groups that we belong have on it. The need for approval to belong to a current or idealized social group is an important motivation and leads to behaviors that legitimize belonging to a particular social group, or depart from those unwanted (ELLEMERS; KORTEKAAS; VOUWERKERK, 1999). By belonging to a particular social group we expect people, 
and consumers in particular, to feel their highest self-esteem. This leads us to the first hypothesis of this study.

- H1: Social identity will have a positive and significant relationship with selfesteem.

On the other hand, some social groups have been characterized by a peculiar transformation in developing countries (SARAIVA, et al., 2015). Sharp social changes have brought a large contingent of consumers to seek more sophisticated products and brands. These new consumers have moved away from a reduced consumption stage to a higher consumption of more improved products. In the last decades these groups have come to desire more sophisticated products and brands. However, this group of consumers has not lost its initial identity. Its relation to luxury and sophistication is still at a certain distance from the very strategy of organizations, even more so in the luxury segment (DUBOIS; DUQUESNE, 1993).

On the other hand, these consumers seek in more sophisticated consumption a self-affirmation of their identity. This can be achieved through brands that make them look more sophisticated than being properly (HENINGS et al, 2012), with brands (not the whole lifestyle) becoming part of the process of building their social identity.

Brands can bridge the gap between a sense of being marginalized in society, and the aspiration of being accepted and distinguished. In this way we hypothesize that $(\mathrm{H} 2)$ the Value of luxury will have a positive and significant relationship with Selfesteem for low income consumers when $(\mathrm{H} 3)$ the Expressiveness of the brand moderates in a significant and positive way the relation between the Value of luxury and the Self-esteem. We also expect that the same moderating role of Brand Expressiveness for $(\mathrm{H} 4)$ the relationship between Social identity and Self-esteem. These hypotheses can be observed in Figure 1. 
DOI: 10.14807/ijmp.v8i3.639

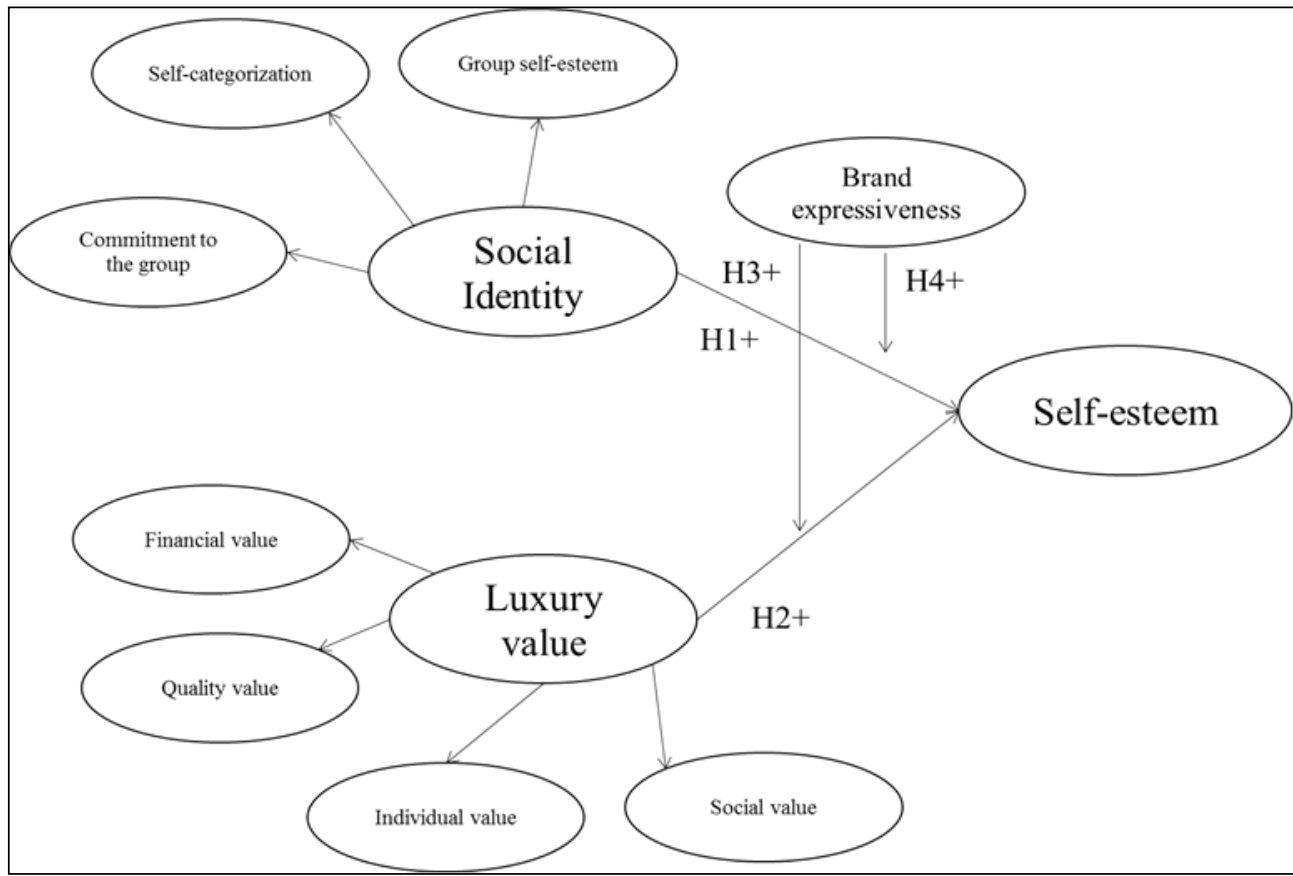

Figure 1: Theoretical model to be tested

\section{RESEARCH METHODOLOGY}

In this section we describe the research design, overall field procedures, analysis criteria and the measurement of the variables used.

\subsection{Universe of research and sample}

The research sample consisted of students with an active consumer profile who could represent the consumption categories sought in this study, belonging to lower-income social classes. The sample was non-probabilistic for convenience because any element of the sample did not have the same possibility of being chosen (MALHOTRA, 2012), given that the collection took place through the web. With this choice, we sought a sample capable of representing the group of people reasonably involved with brands (SELLTIZ; WRIGHTSMAN; COOK, 1987).

The group chosen as a sample for this study has these characteristics, since young students are mostly economically active and are the target of the marketing actions of the organizations with intensive use of brands as a strategy (JOHN, 2009). At the same time, this social group is in the process of affirming its identity as consumers, through the choices of products and brands capable of representing them. In addition, these social subjects have diverse demographic and behavioral characteristics, and can represent the Brazilian population in general. 
INDEPENDENT JOURNAL OF MANAGEMENT \& PRODUCTION (IJM\&P)

http://www.ijmp.jor.br

V. 8, n. 3, July - September 2017

ISSN: 2236-269X

DOI: 10.14807/ijmp.v8i3.639

It also contributes to the choice of students the fact that these stiffens can be located in a convenient access location, in a Higher Education Institution, offering possibility of conducting the study. All students responded to a previous questionnaire to assess their social class, according to the criteria proposed by ABEP (Brazilian Association of Research Companies). Those who scored as low income were invited to participate in the final sample.

\subsection{Research design and procedures}

For the accomplishment of the study a descriptive approach was adopted (MALHOTRA, 2012) in order to observe the operation of the phenomenon, not its causes. We adopted Structural Equation Modeling (SEM) as analysis technique because it allows to simultaneously observe the relationships that involve the phenomenon. Data collection was done through the internet. The students scored as low income were invited to participate in the study with strictly academic intent. A link was sent to the students via email.

The students completed demographic data and, at their choice, indicated their identification or some means of contact to receive the results of the study. The research was conducted between April and June 2016. Luxury value was measured based on Hennigs et al. (2012). Social Identity and Self-esteem were based on Ellemers et al. (1999), and Brand Expressiveness was based on Carrol and Ahuvia (2006).

\subsection{Analysis criteria}

The criteria of analysis followed those pointed out by Hair et al. (2014). The fit of the model initially seeks to achieve convergent and discriminant validity. The convergent validity observes the Average Variance Extracted (AVE), or the proportion of the data in their respective latent variables that is explained. The values should exceed 0.50 , or $50 \%$, indicating that most of the construct is being explained. Then the internal consistency, Cronbach's Alpha and Compound reliability indicators are observed (values should exceed 0.60 and 0,70 respectively).

The discriminant validity is observed by comparing the square root of the AVE of each variable and its correlation with the other variables, and the factorial load of each item, larger in its respective variable than in other variables. Discriminant 
Validity indicates the independence of the constructs between them. The next step is the analysis of the structural model itself.

The coefficient of determination $\left(R^{2}>2 \%\right)$, the relations between the variables, or factor load of the path coefficient and significance ( $p$-value $\leq 5 \%$ ) were observed with Student's t-tests for regressions and correlations of the model. Finally, the coefficients of Predictive Relevance ( $Q^{2}$ greater than zero) and size or force of the effect ( $f^{2}$ above 0.02 ) of the variables of the model are analyzed. $Q^{2}$ evaluates the fit of the model to its prediction and $\mathrm{f}^{2}$ indicates how much each construct is important to the model itself. In a complementary way, the quality of fit indicator of the model, GoF (Goodness of Fit, above 0.36) is observed.

Finally, with all these indicators we performed the interpretation of the model in light of the observed theory and objectives of the study. To test the hypotheses, the Bootstrapping procedure was performed, consisting of a systematic resampling of the data. Hypotheses are accepted for student t test above 1.96 ( $p$-value $\leq 0.05$ ).

\section{RESULTS}

In this section the results of the study will be observed, beginning with the sample until the adjustment indicators of the model.

\subsection{Sample}

A total of 135 questionnaires were received, all valid. Of these, 111 were considered valid for the study because they belong to lower-income class according to the ABEP criteria. Of the total respondents, 53.4\% are women. The mean age was 26.7 years of age with a standard deviation of 2.3 years. All are upper-level business administration students in the majority. Only $2.5 \%$ are in their second graduation.

\subsection{Theoretical model}

The first step sought to achieve the convergent and discriminant validity of the proposed model. The final model resulted in a good fit for these parameters. Table 1 presents the initial results of the convergent validity. The final model did not identify the variable Self-esteem with group by factorial loads below 0.7 . 
INDEPENDENT JOURNAL OF MANAGEMENT \& PRODUCTION (IJM\&P)

http://www.ijmp.jor.br

v. 8, n. 3, July - September 2017

ISSN: 2236-269X

DOI: 10.14807/ijmp.v8i3.639

Table 1: Convergent validity

\begin{tabular}{ccccccc}
\hline Variable & AVE & $\begin{array}{c}\text { Composite } \\
\text { reliability }\end{array}$ & $\mathrm{R}^{2}$ & $\begin{array}{c}\text { Cronbach' } \\
\text { s Alpha }\end{array}$ & Comunality & Redundancy \\
\hline Self-categorization & 0,646 & 0,785 & 0,588 & 0,457 & 0,646 & 0,379 \\
Self-esteem & 0,676 & 0,861 & 0,374 & 0,754 & 0,676 & 0,15 \\
Comitment with the group & 0,766 & 0,867 & 0,7 & 0,7 & 0,766 & 0,527 \\
Quality value & 0,724 & 0,887 & 0,291 & 0,808 & 0,724 & 0,211 \\
Financial value & 0,72 & 0,837 & 0,132 & 0,611 & 0,72 & 0,095 \\
Individual value & 0,669 & 0,91 & 0,802 & 0,876 & 0,669 & 0,533 \\
Social value & 0,655 & 0,904 & 0,747 & 0,867 & 0,655 & 0,488 \\
Brand expressiveness & 0,736 & 0,847 & 0 & 0,659 & 0,736 & 0 \\
\hline
\end{tabular}

Source: The authors

All AVEs were above 0.5 and the other indicators showed good adjustment. Table 2 complements the observation of convergent validity.

Table 2: Other indicators of Convergent validity

\begin{tabular}{ccccccccc}
\hline Variável & 1 & 2 & 3 & 4 & 5 & 6 & 7 & 8 \\
\hline Self-categorization (1) & $\mathbf{0 , 8 0 4 ^ { * }}$ & - & - & - & - & - & - & - \\
Self-esteem (2) & 0,415 & $\mathbf{0 , 8 2 2}$ & - & - & - & - & - & - \\
Comitment with the group (3) & 0,291 & 0,349 & $\mathbf{0 , 8 7 5 *}$ & - & - & - & - & - \\
Quality value (4) & 0,174 & 0,235 & 0 & $\mathbf{0 , 8 5 1 ^ { * }}$ & - & - & - & - \\
Financial value (5) & 0,07 & $-0,082$ & $-0,203$ & 0,073 & $\mathbf{0 , 8 4 8 ^ { * }}$ & - & - & - \\
Individual value (6) & 0,132 & $-0,205$ & $-0,163$ & 0,381 & 0,25 & $\mathbf{0 , 8 1 \mathbf { 8 } ^ { * }}$ & - & - \\
Social value (7) & 0,113 & $-0,047$ & $-0,131$ & 0,284 & 0,252 & 0,626 & $\mathbf{0 , 8 0 9 *}$ & - \\
Brand expressiveness (8) & 0,231 & 0,066 & 0,033 & 0,314 & 0,113 & 0,296 & 0,375 & $\mathbf{0 , 8 5 8 ^ { * }}$ \\
\hline \multicolumn{8}{c}{ Source: The authors } \\
& *Construct AVE square root. & & & &
\end{tabular}

All the square roots of the AVEs were above their correlation with the other variables demonstrating the independence of the constructs among themselves. The discriminant validity was also observed by crossloadings of the items, higher in their respective variables. The GoF setting quality indicator was 0.513 . The indicators of accuracy $\left(\mathrm{Q}^{2}\right)$ and effect $\left(\mathrm{f}^{2}\right)$ of the variables were obtained and are presented in Table 3. 
DOI: 10.14807/ijmp.v8i3.639

Table 3: Accuracy and predictive validity

\begin{tabular}{ccc}
\hline Varible & $\mathrm{Q}^{2}$ & $\mathrm{f}^{2}$ \\
\hline Social identity & - & 0,101 \\
Self-categorization & 0,375 & - \\
Comitment with the group & 0,566 & - \\
Self-esteem & 0,176 & - \\
Value of luxury & - & 0,322 \\
Quality value & 0,211 & - \\
Financial value & 0,098 & - \\
Individual value & 0,524 & - \\
Social value & 0,487 & - \\
Brand expressiveness & - & - \\
\hline
\end{tabular}

Source: The authors

It is observed that all indicators were above the parameters determined in the analysis criteria. Finally, Table 4 shows the test of the hypotheses.

Table 4: Hypotheses

\begin{tabular}{|c|c|c|c|c|c|}
\hline Hypotheses & Relationship & $\begin{array}{c}\text { Original } \\
\text { coefficient }\end{array}$ & T test & $\begin{array}{c}\mathrm{p}- \\
\text { value }\end{array}$ & Status \\
\hline $\mathrm{H} 1$ & Social identity $\rightarrow$ Self-esteem & 0,572 & 2,564 & 0,012 & Confirmed \\
\hline $\mathrm{H} 2$ & Luxury value $\rightarrow$ Self-esteem & 0,239 & 1,859 & 0,066 & Confirmed \\
\hline H3 & $\begin{array}{c}\text { Social identity * Brand expressiveness } \\
\rightarrow \text { Self-esteem }\end{array}$ & $-0,305$ & 1,29 & 0,200 & $\begin{array}{c}\text { Not } \\
\text { Confirmed }\end{array}$ \\
\hline $\mathrm{H} 4$ & $\begin{array}{c}\text { Luxury value * Brand expressiveness } \rightarrow \\
\text { Self-esteem }\end{array}$ & 0,595 & 2,557 & 0,012 & Confirmed \\
\hline - & $\begin{aligned} \text { Social identity } & \rightarrow \text { Commitment to the } \\
& \text { group }\end{aligned}$ & 0,837 & 19,328 & 0,001 & - \\
\hline- & Social identity $\rightarrow$ Self-categorization & 0,767 & 12,851 & 0,001 & - \\
\hline - & Luxury value $\rightarrow$ Quality value & 0,54 & 5,556 & 0,001 & - \\
\hline - & Luxury value $\rightarrow$ Financial value & 0,363 & 3,213 & 0,002 & - \\
\hline - & Luxury value $\rightarrow$ Individual value & 0,895 & 44,372 & 0,001 & - \\
\hline - & Luxury value $\rightarrow$ Valor social & 0,864 & 30,987 & 0,001 & - \\
\hline
\end{tabular}

Source: The authors

Hypothesis H3 was considered not supported because moderation was not observed although the relationship between the variables Social Identity and SelfEsteem remained positive. The results of this study can be observed in a consolidated manner through Figure 2. 
DOI: 10.14807/ijmp.v8i3.639

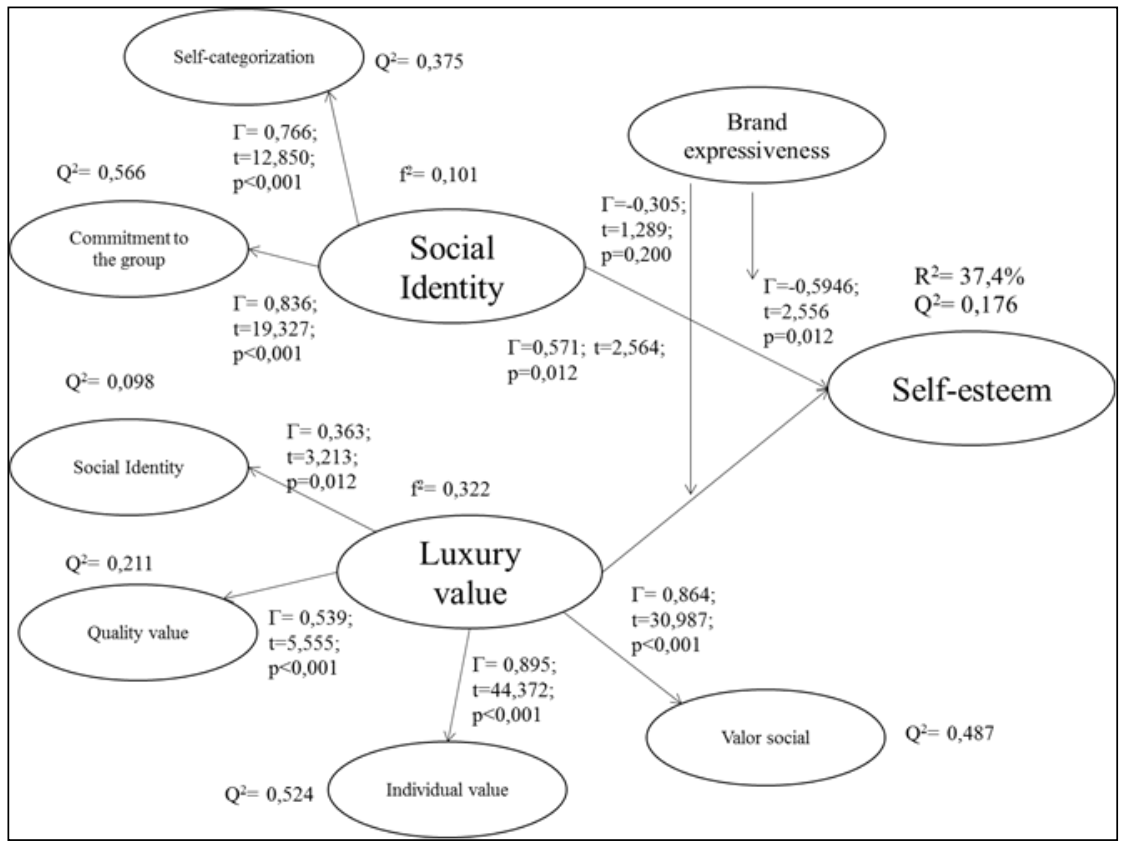

Figure 2: Structural model

Source: The authors

\section{DISCUSSION}

The results of this study describe the importance of brand expressiveness so that consumers of lower income can have a closer relationship with luxury value (DUBOIS; DUQUESNE, 1993) and the construction of their social identity. The brand acts as an element of expansion and construction of the self for these consumers. If the brand expresses their identity they now can consume more sophisticated brands without any discomfort. Brand expressiveness can link their current identity (as being low income) and their aspirational identity (linked to a more sophisticated lifestyle). This is consistent with the definition of Poseurs pointed out by Hennigs et al (2012).

Hypothesis $\mathrm{H} 1$ was confirmed and social identity has a positive and significant relationship with self-esteem $(\Gamma=0.572, \mathrm{t}(499)=2.564, \mathrm{p}=0.012)$. This result shows that the view that social groups have about their members is an important factor influencing low-income consumers' self-esteem. However, we did not identify the dimension Self-esteem in relation to the group in the Social Identity construct.

Lower-income consumers may be seeking to follow another social group different from his current one, even if he recognizes that he is in a lower income group (Social identity $\rightarrow$ Self-categorization: $\Gamma=0.767, \mathrm{t}(499)=12.851, \mathrm{p}<0.001, \mathrm{Q}^{2}=$ $\left.0.375, R^{2}=58.8 \%\right)$ and, more importantly, still has a great affection for its origins (Social identity $\rightarrow$ Commitment to the group: $\Gamma=0.837, \mathrm{t}_{(499)}=19,328, \mathrm{p}<0.001, \mathrm{Q}^{2}=$ 
$\left.0.566, R^{2}=70 \%\right)$. We believe that this result can be explained by the projection of the consumer's self.

He aspires to be part of a social group distinct from his current one, so he acquires more sophisticated goods to reconcile this situation in his/her mind. Belonging to the current social group by itself already stimulates the consumer's selfesteem, so that the extension of identity through the brand does not significantly alter this relationship $(\mathrm{H} 3:=0.305, \mathrm{t}(499)=1.290, \mathrm{p}=0.200)$.

The relationship of this group of consumers with luxury is not direct. Without the moderation of the expressiveness of the brand, the value attributed to luxury does not even lead the consumer to self-esteem in a significant way $(\Gamma=-0.081, t$ $(499)=1.003, p>0.05)$. Only becoming statistically positive and statistically significant $(\mathrm{H} 2=0.239, \mathrm{t}(499)=1.859, \mathrm{p}=0.066)$ after the moderation of the brand as extension of self $(\mathrm{H} 4:=0.595, t(499)=2.557, p=0.012)$.

That is, the brand acts as a symbol that allows the low-income consumer to observe in luxury something that can increase their self-esteem and make their relation with sophistication justifiable despite its origin of few material resources. So much so that the dimensions of the Value of luxury more explained were those referring to intrinsic and psychological benefits such as Social value $\left(Q^{2}=0.487, R^{2}\right.$ $=74.7 \%)$, Individual value $\left(\mathrm{Q}^{2}=0.524, \mathrm{R}^{2}=80.2 \%\right)$ and the Quality Value $\left(\mathrm{Q}^{2}=\right.$ $\left.0.211, R^{2}=29.1 \%\right)$, more than social identity (as part of luxury value) itself $\left(Q^{2}=\right.$ $\left.0.098, R^{2}=13.2 \%\right)$.

The aspirational character of low-income consumer was further reinforced by the fact that the Luxury Value had a greater effect $\left(f^{2}=0.322\right)$ on the Self-esteem explanation $\left(R^{2}=37.4 \%\right)$ than the Social Identity effect $\left(f^{2}=0.101\right)$. These results, taken together, indicate that the lower income consumer observes in sophistication an important aspect of their self-assertion. Again the results observed confirm the aspirational argument.

This study sought to analyze the relations between social identity and the value of luxury as factors of influence on low income consumer when one observes the moderation of brand expressiveness. On the one hand, the pressures of the social group act as a force that drives the judgments and decisions of consumers when mediated by the self-esteem that the consumer possesses. This self-esteem 
INDEPENDENT JOURNAL OF MANAGEMENT \& PRODUCTION (IJM\&P)

http://www.ijmp.jor.br

v. 8, n. 3, July - September 2017

ISSN: 2236-269X

DOI: 10.14807/ijmp.v8i3.639

seems to be in transition from a momentary state caused by experienced situational experiences to a more enduring personality trait by observing that low-income consumers themselves are undergoing a social and material transformation.

It was not surprising, for example, not to identify the dimension Self-esteem by the group within the social identity of the consumer. This feeling of appreciation to the lower income group is not clear because a new social group is more seductive when consuming sophisticated products.

This study contributes for researchers by observing the role of luxury in the life of a consumer not studied in this area of knowledge. Over the past few decades, social mobility has been very marked in developing countries. The classic paradigm of luxury marketing establishes that luxury consumers are the ones with the highest income (DUBOIS; DUQUESNE, 1993).

However, social and economic changes have encouraged the Pousers (HENNIGS, 2012) to gain importance for organizations although they are little studied in the academic field. From the methodological point of view, this study contributes to the relationship between the Luxury Value and Self-Esteem constructs through MEE in a context of low-income consumers. This methodological choice allowed us to describe a phenomenon in ascendancy in society, particularly in emerging markets.

New studies are needed to identify other variables that may be antecedents of low-income consumer self-esteem in the context of sophistication suggested by this study. We believe that the intention to pay premium prices for products can be a relevant variable because it deals with an important aspect in the decision making off lower-income classes. We also suggest that other studies can advance the topic by testing the impacts on specific product categories as well.

For managers, this study points out that a luxury marketing strategy for lowerincome consumers will be more appropriate if it proposes the sophistication and extension of identity through brands that could express low-income consumer's selfaffirmation.

One should not turn away from this consumer profile in the most sophisticated products segment, but rather develop offers that may occupy a neglected space in the strategy of organizations dealing with luxury. It is not a matter of doing the down 
INDEPENDENT JOURNAL OF MANAGEMENT \& PRODUCTION (IJM\&P)

http://www.ijmp.jor.br

v. 8, n. 3, July - September 2017

ISSN: 2236-269X

DOI: 10.14807/ijmp.v8i3.639

trade simply, but to find alternatives that can serve this audience more properly in a psychological manner.

\section{REFERENCES}

BAGOZZI, R. P.; KYU-HYUN, L. (2002) Multiple routes for social influence: The role of compliance, internalization, and social identity. Social Psychology Quarterly, v. 65 , n. 3, p. 226-247.

BELK, R. W. (1998) Possessions and the Extended Self. Journal of Consumer Research, v. 2, n. 15, p. 139-168.

CARROLL, B.; AHUVIA, A. (2006) Some Antecedents and Outcomes of Brand Love. Marketing Letters, v. 17, Issue 2, p. 79-89.

CAST, A. D.; BURKE, P. J. (2002) A Theory of Self-Esteem. Social Forces, v. 80, n. 3, p.1041-1068.

DAY, E. (1989) Share Of Heart: What Is It And How Can It Be Measured? The Journal of Consumer Marketing, v. 6, n. 1, p. 5-12.

DUBOIS, B.; DUQUESNE, P. (1993) The Market for Luxury Goods: income Versus Culture. European Journal of Marketing, v. 27, n. 1, p. 35-44.

EAGLY, A. H.; CHAIKEN, S. (1993) The psychology of attitudes. Fort Worth, TX: Harcourt.

ELLEMERS, N.; KORTEKAAS, P.; OUWERKERK, J. W. (1999) Self-categorisation, commitment to the group and group self-esteem as related but distinct aspects of social identity. European Journal of Social Psychology, v. 29, p. 371-389.

ESTADÃO, (2012) Brasileiro substitui itens básicos por sofisticados. Available in http://www.estadao.com.br/blogs/jt-seu-bolso/2012/05/13/brasileiro-substitui-itensbasicos-por-sofisticados/, access in 12, June, 2015.

EUROMONITOR, Luxury goods Market Sizes Retail Value RSP | US\$ mn |Fixed (2014) Exchange Rates, available in < http://www.euromonitor.com/>, access at June,12,2015.

EXAME (2013) O novo salto do consumo se apóia na sofisticação. Available in <http://exame.abril.com.br/revista-exame/edicoes/1055/noticias/o-novo-salto-doconsumo, access in june, 12, 2015.

GECAS, V. (1982) The Self-concept. Annual Review of Sociology, v. 8, p. 1-33.

HAIR JR, et al. (2014) A primer on partial least squares structural equation modelling (PLS-SEM). SAGE Publications.

HAN, Y.; NUNES, J.; DRÈZE, X. (2010) Signaling Status with Luxury Goods: The Role of Brand Prominence. Journal Of Marketing. v. 74, n. 4, p. 15-30.

HENNIGS, N.; WIEDMANN, K.; KLARMANN, C.; STREHLAU, S.; GODEY, B.; Pederzoli; D.; OH, H. (2012) What is the Value of Luxury? A Cross-Cultural Consumer Perspective. Psychology \& Marketing, v. 29, n. 12, p. 1018-1034.

JOHN, D. R. (2009) Stages of consumer socialization. The development of consumer knowledge, skills, and values, from childhood to adolescence.In 
"Handbook of consumer psychology". Ed. Curtis P. Haugtvedt, Paul M. Herr, Frank R. Kardes, York, NY: Lawrence Erlbaum Associates, p. 297-348

KAPFERER, J. N. (2014 ) Lecture Monaco Symposium on Luxury.

KAPFERER, J. N. (2015) Kapferer on luxury: How Luxury brands can grow yet remain rare. Kogan Page. p 17.

KEMP, S. (1998) Perceiving Luxury and Necessity. Journal of Economic Psychology, v. 9, n. 5, p. 591-606.

LEIBENSTEIN, H. (1950). Bandwagon. Snob, and Veblen Effects in the Theory of Consumers' Demand. The Quarterly Journal of Economics, v. 64, n. 2, p. 183207.

MALHOTRA, N. (2012) Pesquisa de Marketing: Uma orientação aplicada. Bookman: Porto Alegre, 6a Edição.

NGUYEN, B.; SIMKIN, L. (2013) The Dark Side of CRM: Advantaged and Disadvantaged. Journal of Consumer Marketing, v. 30, n. 1, p. 17-30.

ROSENBERG, M. (1981) The Self-Concept: Social Product and Social Force. In M. Rosenberg \& R. H. Turner (Eds.), Social Psychology: Sociological Perspectives (pp. 593-624). New York: Basic.

SARAIVA, L. F. O.; REZENDE, J. C. O.; REIS, J. V. S.; INÁCIO, M. D.; SHUCMAN, L. V. (2015) A nova classe média: repercussões psicossociais em famílias brasileiras. Psicologia USP, v. 26, n. 1, p. 52-61.

SELLTIZ, C.; WRIGHTSMAN, L. S.; COOK, S. W. (1987) Métodos de pesquisa nas relações sociais. 2.ed. São Paulo: E.P.U.

SHIMP, T. A.; MADDEN, T. J. (1988) Consumer-Object Relations. Advances in Consumer Research, v. 15, n. 1, p. 163-168.

STREHLAU, S. (2008). Marketing do luxo. São Paulo: Cengage Learning, 155p.

VIGNERON, F.; JOHNSON, L. W. (1999) A review and a conceptual framework of prestige-seeking consumer behavior. Academy of Marketing Science Review, V. 1999, n. 1, p. 1-15.

WIEDMANN, K.-P.; HENNIGS, N.; SIEBELS, A. (2007) Measuring consumers' luxury value perception: A cross-cultural framework. Academy of Marketing Science Review, v. 2007, n. 7, p. 1-21.

XIANCHI, D.; FISHBACH, A. (2014). How Nonconsumption Shapes Desire. Journal of Consumer Research, v. 41, n. 4, p. 936-952.

YE, S.-H.; LIU, X.-T.; SHI, S.-Y. (2015). The Research of Status's Influence on Consumers' Self-Brand Connection with Luxury Brands: Moderating Role of SelfEsteem and Vanity. Open Journal of Business and Management, v. 3, p. 11-19. 